\title{
Peptide YY as a growth factor for intestinal epithelium
}

\author{
Peter J. Mannon* \\ Mucosal Immunity Section, Laboratory of Clinical Investigation, National Institute of Allergy and Infectious Diseases, National Institutes of Health, \\ 10 Center Drive, Rm 11N238, Bethesda, Maryland 20892, USA
}

02 April 2001; accepted 14 July 2001

\begin{abstract}
Peptide YY is an abundant distal gut hormone that may play a significant role in intestinal epithelial proliferation. Gut epithelial cells express specific receptors for PYY, PYY induces proliferation in intestinal cells in vivo and in vitro, and the Y1 receptor subtype couples to mitogenic signaling pathways. In addition to proposed physiologic effects on gut mucosal maintenance, PYY proliferative effects may be hypothesized to contribute to pathophysiologic consequences of stimulated growth. (C) 2002 Elsevier Science Inc. All rights reserved.
\end{abstract}

Keywords: Peptide YY; Receptor; Growth; Epidermal growth factor receptor; Mitogen-activated protein kinase; Epithelium

\section{Introduction}

Peptides play a key role in activating proliferation signals within the gastrointestinal epithelium. The best known factors include ligands for classic receptor tyrosine kinases such as epidermal growth factor (EGF), transforming growth factor- $\alpha$ (TGF- $\alpha)$ and insulin-like growth factor (IGF), but gut endocrine peptides that signal through alternative families of receptors also exert growth effects, with gastrin as a well-characterized example. Gut peptides that have been proposed as epithelial growth factors include enteroglucagon [33], glucagon-like peptide-2 [35] and monitor peptide [23] as well as those with mitogenic effects on neoplastic cells such as gastrin releasing peptide, bombesin, and neurotensin. Peptide YY has been characterized primarily for its postprandial inhibitory effects on the gastrointestinal tract, inhibition of gastric emptying, gut motility, and gastrointestinal mucosal secretion, fulfilling its role as an enterogastrone factor. However, observational studies of PYY production in the gut epithelium hinted that PYY might play a role in epithelial proliferation. An association between elevated serum PYY levels and trophic responses of the small intestinal mucosa, in a model of limited enterectomy, was the first evidence suggesting a potential role for PYY in gut epithelial growth [61]. Further studies demonstrated receptors for PYY on gut epithelial cells thereby 2240

* Corresponding author. Tel.: +1-301-594-0593; fax: +1-301-402-

E-mail address: pmannon@niaid.nih.gov (P.J. Mannon). providing a mechanism for direct proliferative effects on cells. Finally subsequent data showed that PYY and the closely related NPY induce proliferation in a variety of cell and tissue models. This biological effect is complemented by biochemical data showing that the Y1 receptor can couple to intracellular signaling molecules that are well recognized for their role in proliferative responses. This review will examine the evidence supporting a role for PYY in gut epithelial growth and propose a medical hypothesis for PYY in gut epithelial pathophysiology that has proliferation as a key component.

\section{Receptors for peptide YY are localized to gut epithelial cells}

In order for PYY to be able to exert a biological effect directly on a cell, that cell must express cell surface receptors that specifically bind PYY. Studies using whole gut tissue or stripped mucosa preparations showed that PYY or NPY could inhibit short circuit current or apical chloride secretion in a variety of species including the rabbit $[6,21$, 22,34], rat [16,60], guinea pig [49], and human [50]. However, it was not possible to tell whether PYY or NPY had direct effects on the epithelial cells, consistent with epithelial cell expression of Y receptors, or whether the PYY effects were indirectly exerted by intervening neurotransmitter or other gut peptide networks included in the tissue preparation (even if PYY/NPY responses persisted after tetrodotoxin administration). Using techniques that identify 
specific $\mathrm{Y}$ receptor binding activity, $\mathrm{Y}$ receptor mRNA production, and $\mathrm{Y}$ receptor protein expression within thin sections of gut tissue, it was confirmed that gut epithelial cells could indeed express Y receptors. Receptor autoradiography, a technique that allows radiolabeled peptides to specifically bind to receptors located within slide-mounted tissue sections, showed Y2 subtype receptors largely restricted to the crypt epithelium of rat small intestine with little or no receptor binding in the rat colon [71]. In contrast, receptor autoradiography also showed PYY and NPY binding sites throughout the entire epithelium of the rabbit colon [44]. In situ hybridization techniques identified mRNA for the Y1 receptor subtype within basal crypt epithelial cells of the human colon [72]. By comparison, the reverse transcription polymerase chain reaction (PCR) detected $\mathrm{Y} 2$ receptor mRNA in epithelial cells isolated from the rat small and large intestine and Y5 mRNA in small intestinal epithelium (this is in contrast to the receptor autoradiography results where a relative lack of $Y$ receptor binding activity in the rat colon compared to the small intestine suggests much less functional expression of the $\mathrm{Y}$ receptor protein given comparable detection of mRNA) [29]. Lastly, a specific antibody to the human $\mathrm{Y} 1$ receptor showed $\mathrm{Y} 1$ receptor protein expressed throughout the colonic crypt epithelium in humans [43], suggesting that the receptor protein is rather long lived since Y1 receptor mRNA production is limited to the basal crypt cells. Confocal microscopy of Y1 receptor immunofluorescent antibody staining in human colon showed that the Y1 receptor protein was distributed along the basolateral membrane, where receptors would be accessible to PYY released into the lamina propria by surrounding PYYcontaining enteroendocrine cells

\section{Proliferative effects of peptide YY: observations in animals}

Initial suggestions that PYY might be associated with a proliferative effect in the gut epithelium came from observations of elevated PYY serum levels following intestinal resection $[27,61]$. Within days of intestinal resection PYY serum levels exceeded peak postprandial levels, coinciding with peak epithelial mitotic activity. Similar results of PYY serum elevations were noted after resection of $75 \%$ of the small intestine in dogs and resection of $40-200 \mathrm{~cm}$ of ileum humans [4,5,7]. Apropos of PYY serum elevations in the setting of a proliferative epithelial state, several studies showed that classic peptide growth factors can also stimulate PYY release. Following TPN therapy, administration of EGF stimulates significant elevations in PYY serum levels which may or may not be accompanied by elevations in gastrin or enteroglucagon levels [25,52]; EGF, insulin-like growth factor-I and TGF $\alpha$ induce elevated PYY serum levels in a mouse and dog model [38]. Keratinocyte growth factor can also increase blood PYY, enteroglucagon, gastrin, and GLP-1 levels [54]. Lastly, in an experiment of nature, small intestinal hypertrophy was seen in the setting of a metastatic neuroendocrine tumor found to be secreting high levels of PYY (along with glucagon-like peptides 1 and 2) [12]. The primary tumor likely derived from a hindgut enteroendocrine L cell, a subset of PYY-secreting cells that co-release enteroglucagon peptides [20]. These observations establish an association of PYY with clinical settings characterized by proliferative responses and an association with proliferative factors themselves but do not prove PYY-caused proliferation

Controlled experimental studies went further to demonstrate a causal role for PYY inducing a proliferative effect on the gut epithelium: intraperitoneal (i.p.) administration of PYY (t.i.d. for 10-14 days) was associated with significant increases in gut wet weight, DNA, and protein content in adult mice (nursing rats had more modest results and only in the small intestine, consistent with the functional gut receptor distribution in rats [71]) [24]. Also noteworthy is a report of PYY infusion preventing mucosal atrophy during total parenteral nutrition. When PYY was co-infused with TPN solutions in rats for 7 days, compared to rats who got TPN alone there was significant amelioration of the small and large bowel protein and mass reductions with near total preservation of villus height [15]. These findings are in contrast to other studies that were not able to detect significant proliferative effects for PYY during parenteral administration even at levels mimicking post-enterectomy states. In one study, rats were treated with PYY-containing miniosmotic pumps subcutaneously (s.c.) for 12 days and allowed to feed ad libitum [61]. It is possible that exogenous proliferative effects could not be detected against the background activity of endogenous PYY was released by feeding, similar to the increased efficacy of keratinocyte growth factor in TPN-fed compared to orally fed rats [28]. Another study treated rats on TPN for three days with or without co-infusion of PYY; during this time the rats had no oral food intake and crypt cell proliferation was measured between groups [26]. The duration of treatment may not have been long enough to see a difference, and only the highest PYY dose used in this study was in the range of proliferation-inducing doses used in similar experimental designs. Furthermore, in the setting of TPN-induced gut atrophy, perhaps the action of PYY is less proliferative and more anti-apoptotic as reflected by the preservation of gut mass and architecture. Regardless it is important to take into account the details of experimental design when comparing conflicting results in apparently similar studies.

\section{Proliferative effects of peptide YY: observations in vitro}

Peptide YY and NPY can induce proliferative effects in a variety of cell types. Activation of the Y2 receptor subtype by NPY on rat renal epithelial cells stimulates DNA synthesis and increases cell numbers [70]. Both PYY and NPY 
increase radiolabeled thymidine incorporation into DNA after binding to the Y1 receptor subtype in human vascular smooth muscle cells [18], and NPY has similar mitogenic effects on rat vascular smooth muscle cells [75]. When the human Y1 receptor is expressed in a non-transformed intestinal epithelial cell line derived from rat small intestine (IEC-6 cells), PYY treatment increases cell numbers [45], confirming the ability to stimulate proliferation in a gut epithelial cell. The $\mathrm{Y} 1$ receptor is also a subtype that is characteristic of human colonic epithelium, being expressed endogenously in the human colonic adenocarcinoma cell line HT-29 following differentiation [46] as well as constitutively expressed in normal human colon epithelium [43, 72].

That the $\mathrm{Y} 1$ receptor could activate a mitogenic response is not unexpected given that it belongs to the $G$ proteincoupled superfamily of receptors (GPCRs), and specifically is coupled primarily through the $G_{i}$ and $G_{o}$ subtypes. $G_{i^{-}}$ and $\mathrm{G}_{\mathrm{o}}$-coupled receptors can activate mitogen-activated protein kinase (MAPK) and cell proliferation $[14,30,31,39$, $55,68,69]$. The $\mathrm{G}_{\mathrm{i}^{-}}$and $\mathrm{G}_{\mathrm{o}}$-protein subtypes are pertussis toxin-sensitive and inhibit adenylate cyclase upon receptor activation $[1,32,36,47,62,67]$. This signal is responsible for PYY/NPY inhibitory effects on apical chloride secretion in gut epithelial cells.

In recent years general mechanisms for coupling $\mathrm{G}$ protein-associated receptors to mitogenic pathways have been demonstrated. Although GPCRs offer a potential alternative pathway to classic receptor tyrosine kinases (RTKs), such as the EGFR, for transducing extracellular growth stimuli, many examples exist of GPCRs actually transactivating RTKs as part of their own mitogenic signaling pathway. Activation of GPCRs have lead to the phosphorylation of the EGFR [17,66], PDGFR [40], IGF-1R [57], and p185 ${ }^{\text {neu }}($ HER-2/Erb-2) [17] in the absence of the classic receptor tyrosine kinase cognate ligands. The mechanisms by which GPCRs transactivate RTKs are varied and involve intracellular, and even extracellular [56], signals. One wellcharacterized mechanism for GPCR transactivation of the EGFR involves the $\mathrm{G}$ protein $\beta \gamma$-subunit activating other non-receptor tyrosine kinases, such as Src, either through the PI3-kinase [41] or the proline-rich tyrosine kinase (Pyk2) [11,63], but in other circumstances the way $\beta \gamma$ subunits couple to Src is not clear [42]. In the pathway that couples the human Y1 receptor to MAPK phosphorylation, $\beta \gamma$-subunits clearly couple the Y1 receptor to EGF receptor involvement in the MAPK pathway. Furthermore Src kinase activity is active in the Y1R-MAPK pathway but it is unclear if it is acting between the Y1R and the EGFR, the EGFR and MAPK or in both locations. Finally, protein kinase $\mathrm{C}$ (PKC) plays a major role in the signaling pathway between the Y1 receptor and MAPK, clearly acting between the EGFR and MAPK (Fig. 1). PKC may activate MAPK in either a Ras-dependent $[47,48]$ or Ras-independent $[2,13$, 37] manner, as seen in other models; in Chinese hamster ovary fibroblasts, the transfected human Y1 receptor needs

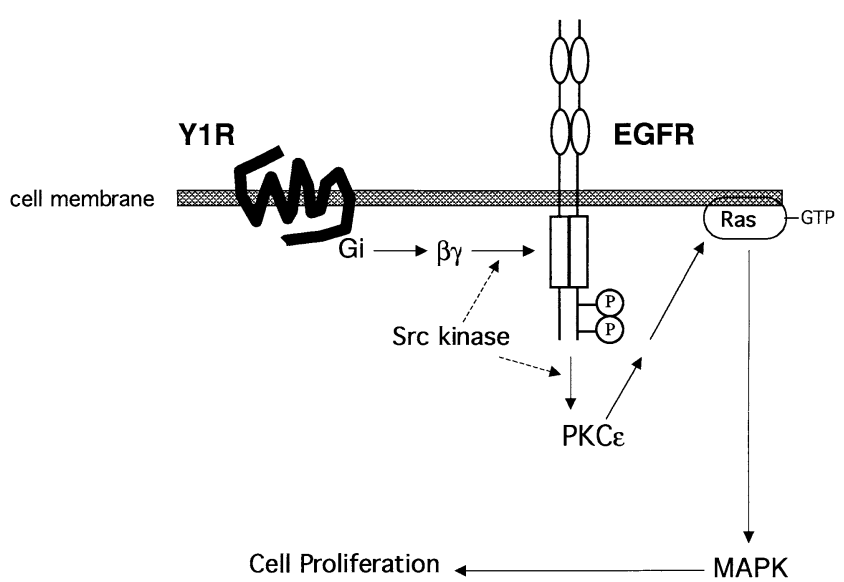

Fig. 1. Proposed signaling pathway for mitogen-activated protein kinase (MAPK) phosphorylation by PYY-activated Y1 receptors in IEC-6 cells. In rat intestinal epithelial cells (IEC-6 cells) transfected with the human Y1 receptor, PYY binding stimulates MAPK phosphorylation. This pathway requires $\beta \gamma$ subunits, EGF receptor tyrosine kinase activity, non-receptor tyrosine kinase activity (Src kinase), and protein kinase C (PKCe). Src kinase may act either proximally or distally to the EGFR, and PKC likely links the pathway to Ras/Raf activation upstream of MAPK.

both PKC and Ras for activation of MAPK [47]. Of interest to gastrointestinal cell-specific growth pathways is that of all the isoforms detected in the IEC-6 cell model, only the $\mathrm{PKC} \epsilon$ isoform was activated by $\mathrm{PYY}$ in the $\mathrm{Y} 1$ receptorexpressing IEC-6 cells. PKC $\epsilon$ is an isoform that has been specifically linked to mitogenic effects in gut epithelium, where its over-expression can induce unregulated growth in non-tumorigenic colonic epithelial cells [51]. The EGFR is a crucial component in PYY-induced growth in the IEC-6 cells as inhibition of EGFR kinase activity blocks the growth response to both EGF and PYY [45].

\section{Proposed role for PYY gut epithelial growth effects in human health and disease}

We can only speculate at present on the physiologic relevance of the proliferative effects of PYY in the absence of studies done in mutant animal models, for instance, and without precise knowledge of the hierarchical and redundant networks that regulate epithelial growth. However, the accumulated data do support a role for PYY eliciting a proliferative response from gut epithelia. Perhaps an additional action to its role as the "enterogastrone," high PYY serum levels seen in malabsorptive states sustain an adaptive response for the intestinal mucosa to maximize surface area in an effort to optimize nutrient absorption. Similarly the quotidian nutrient-stimulated PYY release signals the mucosa to maintain itself for efficient digestion and absorption of ingested energy sources (and conserving resources directed toward gut mucosal maintenance during periods of starvation). However, a more intriguing question is whether the proliferative effect exerted by PYY can contribute to pathophysiologic outcomes as well. 
Peptide YY is released in response to oral nutrient ingestion. Characteristically it is released in proportion to both the calorie content of a meal and its energy source composition. In a study of human volunteers, increasing ingested calories of an identical meal lead to larger and longer lived serum levels of PYY [3]. Isocaloric meals of only fat, carbohydrate, or protein induced the highest levels of serum PYY after the fat meal, followed by carbohydrates and then protein [3]. Additionally it has been shown that direct intracolonic instillation of digestion products of fats, and to a lesser degree carbohydrates and proteins, stimulates PYY release [64]. In settings of acute or chronic fat malabsorption (infectious enteritis or pancreatic insufficiency, e.g.) basal PYY serum levels are higher compared to controls [53]. In trying to draw a line between PYY release and unintended consequences of stimulated proliferation, it is worth noting that the two factors that determine the largest release of PYY, namely high calorie and high fat meals, are also implicated as environmental risk factors for colon cancer $[59,73,74]$. We hypothesize that PYY actions on the gut epithelial receptor could contribute to the biological links between dietary exposure and colon cancer risk.

The accepted model of sporadic colon cancer pathogenesis is based on the proposed accumulation of mutations in tumor suppressor and growth-promoting genes resulting in a cell with transformed phenotype and unregulated growth [19]. In the absence of inherited risk factors such as mismatch repair gene defects, the susceptibility to mutation largely depends on the proliferation rate (which determines the probability of mutation risk by certain classes of mutagen), the apoptosis rate (which determines the interval that cells are susceptible to accumulate mutations), and exposure to mutagens (dose, potency, and the ability to neutralize their effects before DNA damage occurs). In this setting, we hypothesize that PYY could increase the colonic crypt cell proliferation rate, on average, in persons consuming a high calorie, high fat diet $[8-10,65]$. The rationale for this is that a higher proliferation rate in the colonic crypt, assuming a dose-response effect to meal-induced PYY release, would increase the probability of acquiring mutations in epithelial cells during exposure to mutagens encountered in the gut lumen. In experimental models of colon cancer induced by mutagen administration, the rate of adenomatous polyp and colon cancer is accelerated when animals are placed concurrently on a high fat diet [58]. Even administration of oral fat alone increases the proliferation index in colonic crypts in rodents and humans $[8-10,65]$. These data lend support to the hypothesis that PYY could potentially modulate risk of colon cancer in response to diet exposures by positively influencing the proliferation rate in colonic crypts.

In summary, we have reviewed animal data demonstrating PYY growth effects on gut epithelium, Y receptors expressed by gut epithelial cells in many species including humans, and Y receptor coupling to MAPK kinase activation and signaling molecules involved in gut epithelial growth. Future studies of the actual role PYY plays in normal gut proliferative responses will need to use models such as in vivo immunoneutralization of PYY or PYY knockout animals to show that the proliferative response to ingested fats can be blocked, for instance. The proportional contributions of PYY and co-released peptide hormones such as enteroglucagon and glicentin to proliferative responses will need to be defined. In addition the pharmacology of the PYY receptor will need to be elucidated particularly relating to the modulation of PYY activity by receptor desensitization and downregulation in the setting of constant (as in malabsorption states) or repeated (as in daily feeding cycles) PYY exposure. This is particularly important when PYY receptor transactivation of the EGFR can be expected to modulate its activity as well. Results of such studies will establish a position for PYY in the hierarchy of growth and provide models for human PYY responses. Such studies could also provide the rationale for disease prevention strategies and studies of PYY/Y receptor geneenvironment interactions.

\section{References}

[1] Adams SR, Harootunian AT, Buechler YJ, Taylor SS, Tsien RY. Fluorescence ratio imaging of cyclic AMP in single cells. Nature 1991;349:694-7.

[2] Adomeit A, Graness A, Gross S, Seedorf K, Wetzker R, Liebman, C. Bradykinin B2 receptor-mediated mitogen-activated protein kinase activation in COS-7 cells requires dual signaling via both protein kinase $\mathrm{C}$ pathway, and epidermal growth factor receptor transactivation. Mol. Cell. Biol.;1999;19:5289-97.

[3] Adrian TE, Ferr, GL, Bacarese-Hamilton AJ, Fuessl HS, Polak JM, Bloom SR. Human distribution and release of a putative new gut hormone, peptide YY. Gastroenterology 1985;89:1070-7.

[4] Adrian TE, Savage AP, Fuessl HS, Wolfe K, Besterman HS, Bloom SR. Release of peptide YY (PYY) after resection of small bowel, colon or pancreas in man. Surgery 1987;101:715-9.

[5] Adrian TE, Thompson JS, Quigley EMM. Time course of adaptive regulatory peptide changes following massive small bowel resection in the dog. Dig Dis Sci 1996;41:1194-1203.

[6] Ballantyne GH, Goldenring JR, Fleming FX, Rush S, Flint JS, Fielding LP, Binder HJ, Modlin IM. Inhibition of VIP-stimulated ion transport by a novel Y-receptor phenotype in rabbit distal colon. Am J Physiol 1993;264:G848-G854.

[7] Bilchik AJ, Hines OJ, Adrian TE, Skotzko MJ, McFadden DW, Zinner MJ, Ashley SW. Early regional expression and secretion of peptide YY and enteroglucagon after massive resection of small bowel. J Am Coll Surg 1995;180:417-26.

[8] Bird RP, Medline A, Furrer R, Bruce WR. Toxicity of orally administered fat to the colonic epithelium. Carcinogenesis 1985;6:1063-6.

[9] Bird RP, Stamp D. Effect of a high fat diet on the proliferative indices of murine colonic epithelium. Cancer Lett 1986;31:61-7.

[10] Bird RP, Stamp D. Effect of high fat diet on the murine colonic epithelium. Cancer Lett 1986;31:61-7.

[11] Bokemeyer D, Schmitz U, Kramer, HJ. Angiotensin II-induced growth of vascular smooth muscle cells requires an src-dependent activation of the epidermal growth factor receptor. Kidney Int 2000; 58:549-58.

[12] Byrne MM, McGregor GP, Barth P, Rothmund M, Goke B, Arnold R. Intestinal proliferation and delayed intestinal transit in a patient with a GLP-1-, GLP-2- and PYY-producing neuroendocrine carcinoma. Digestion 2001;63. 
[13] Cai H, Smola U, Wixler V, Eisenmann-Trappe I, Diaz-Meco J, Moscat J, Rapp U, Cooper GM. Role of diacylglycerol-regulated protein kinase $\mathrm{C}$ isotypes in growth factor activation of the Raf-1 protein kinase. Mol Cell Biol 1997;17:732-41.

[14] Chambard JG, Paris S, L'Allemain G, Pouyssegur J. Two growth factor signalling pathways in fibroblasts distinguished by pertussis toxin. Nature 1987;326:800-3.

[15] Chance WT, Zhang X, Balasubramaniam A, Fischer JE. Preservation of intestine protein by peptide YY during total parenteral nutrition. Life Sci 1996;58:1785-94.

[16] Cox HM, Cuthbert AW, Hakanson R, Wahlstedt C. The effect of neuropeptide $\mathrm{Y}$ and peptide $\mathrm{YY}$ on electrogenic ion transport in rat intestinal epithelia. J Physiol (Lond) 1988;398:65-80.

[17] Daub H, Weiss FU, Wallasch C, Ullrich A. Role of transactivation of the EGF receptor in signalling by G-protein-coupled receptors. Nature 1996;379:557-60.

[18] Erlinge D, Brunkwall J, Edvinsson, L. Neuropeptide Y stimulates proliferation of human vascular smooth muscle cells: cooperation with noradrenaline, and ATP. Regul Peptides 1994;50:259-65.

[19] Fearon ER, Vogelstein, B. A genetic model for colorectal tumorigenesis. Cell 1990;61:759-67.

[20] Fiocca R, Rindi G, Capella C, Grimelius L, Polak JM, Schwartz TW, Yanaihara N, Solcia, E. Glucagon, glicentin, proglucagon PYY, PP, and proPP-icosapeptide immunoreactivities of rectal carcinoid tumors, and related non-tumor cells. Regul. Peptides 1987;17:9-29.

[21] Flint JS, Ballantyne GH, Goldenring JR, Fielding LP, Modlin, I. M. Neuropeptide $\mathrm{Y}$ inhibition of vasoactive intestinal polypeptide-stimulated ion transport in the rabbit distal colon. Arch Surg 1990;125: 1561-3.

[22] Friel DD, Miller RJ, Walker, MW. Neuropeptide Y: a powerful modulator of epithelial ion transport. Br J Pharmacol 1986;88:42531.

[23] Fukuda M, Fujiyama Y, Sasaki M, Andoh A, Bamba T, Fushiki T. Monitor peptide (rat pancreatic secretory trypsin inhibitor) directly stimulates the proliferation of the nontransformed intestinal epithelial cell line, IEC-6. Digestion 1998;59:326-30.

[24] Gomez G, Zhang T, Rajaraman S, Thakore KN, Yanaihara N, Townsend CM, Greeley GH. Intestinal peptide YY: ontogeny of gene expression in rat bowel and trophic actions on rat and mouse bowel. Am J Physiol 1995;268:G71-G81.

[25] Goodlad RA, Ghatei MA, Domin J, Bloom SR, Gregory H, Wright NA. Plasma enteroglucagon, peptide $Y Y$, and gastrin in rats deprived of luminal nutrition, and after urogastrone-EGF administration: a proliferative role for PYY in intestinal epithelium? Experientia 1989; 45:168-9.

[26] Goodlad RA, Ghatei MA, Domin J, Bloom SR, Wright NA. Is peptide YY trophic to the the intestinal epithelium of parenterally fed rats? Digestion 1990;46:177-81.

[27] Goodlad RA, Lenton W, Ghatei MA, Adrian TE, Bloom SR, Wright NA. Effects of an elemental diet, inert bulk and different types of dietary fibre on the response of the intestinal epithelium to refeeding in the rat and relationship to plasma gastrin, enteroglucagon, and PYY concentrations. Gut 1987;28:171-80.

[28] Goodlad RA, Mandir N, Meeran K, Ghatei MA, Bloom SR, Playford RJ. Does the response of the intestinal epithelium to keratinocyte growth factor vary according to the method of administration? Regul. Peptides 2000;87:83-90.

[29] Goumain M, Voisin T, Lorinet, A-M, Laburthe M. Identification and distribution of mRNA encoding the Y1, Y2, Y4, and Y5 receptors for peptides of the PP-fold family in the rat intestine and colon. Biochem Biophys Res Comm 1998;247:52-6.

[30] Gupta SK, Gallego C, Lowndes JM, Pleiman CM, Sable C, Eisfelder B, Johnson GL. Analysis of the fibroblast transformation potential of GTPase-deficient gip2 ongogenes. Mol Cell Biol 1992;12:190-7.

[31] Hawes BE, van Biesen T, Koch WJ, Luttrell LM, Lefkowitz RJ. Distinct pathways of $\mathrm{G}_{\mathrm{i}}$ - and $\mathrm{G}_{\mathrm{q}}$-mediated mitogen-activated protein kinase activation. J Biol Chem 1995;270:17148-53.
[32] Herzog H, Hort YJ, Ball HJ, Hayes G, Shine J, Selbie LA. Cloned human neuropeptide $\mathrm{Y}$ receptor couples to two different second messenger systems. Proc Natl Acad Sci USA 1992;89:5794-8.

[33] Holst JJ. Gut glucagon, enteroglucagon, gut glucagon-like immunoreactivity, glicentin-current status. Gastroenterology 1983;84:160213.

[34] Hubel KA, Renquist KS. Effect of neuropeptide Y on ion transport by the rabbit ileum. J Pharmacol Exp Ther 1986;238:167-9.

[35] Jasleen J, Shimoda N, Shen ER, Tavakkolizadeh A, Whang EE, Jacobs DO, Zinner MJ, Ashley SW. Signaling mechanisms of glucagon-like peptide 2-induced intestinal epithelial cell proliferation. J Surg Res 2000;90:13-8.

[36] Kassis S, Olasmaa M, Terenius L, Fishman, P. H. Neuropeptide Y inhibits cardiac adenylate cyclase through a pertussis toxin-sensitive G protein. J Biol Chem 1987;262:3429-31.

[37] Kolch W, Heideicke G, Kochs G, Hummel R, Vahidi H, Mischak H, Finkenzeller G, Marme D, Rapp U. Protein kinase C alpha activates Raf-1 by direct phosphorylation. Nature 1993;364:249-252.

[38] Lee HM, Udupi V, Englander EW, Rajaraman S, Coffey RJ, Greeley GH. Stimulatory actions of insulin-like growth factor-I and transforming growth factor-a on intestinal neurotensin and peptide YY. Endocrinology 1999;140:4065-9.

[39] Lettorio JJ, Coughlin SR, Williams LT. Pertussis toxin-sensitive pathway in the stimulation of c-myc expression and DNA synthesis by bombesin. Science 1986;234:1117-9.

[40] Linseman DA, Benjamin CW, Jones DA. Convergence of angiotensin II and platelet-derived growth factor (PDGF) receptor signaling cascades in vascular smooth muscle cells. J Biol Chem 1995;270:12563-8.

[41] Lopez-Illasaca M, Crespo P, Pellici G, Gutkind JS, Wetzker R. Linkage of G protein-coupled receptors to the MAPK signaling pathway through PI 3-kinase gamma. Science 1997;275:394-7.

[42] Luttrell LM, Della Rocca GJ, Van Biesen T, Luttrell DK, Lefkowitz RJ. Gbg subunits mediate Src-dependent phosphorylation of the epidermal growth factor receptor. J Biol Chem 1997;272:4637-44.

[43] Mannon PJ, Kanungo A, Mannon RB, Ludwig, K.A. Peptide YY/ neuropeptide Y Y1 receptor expression in the epithelium, and mucosal nerves of the human colon. Regul. Peptides 1999;83:11-9.

[44] Mannon PJ, Hernandez EJ, Vigna SR, Taylor IL. Localization of specific binding sites for peptide $\mathrm{YY}$ in the rabbit gastrointestinal tract. Gastroenterology 1991;100:A654.

[45] Mannon PJ, Mele JM. The peptide YY receptor activates mitogenactivated protein kinase and proliferation in gut epithelial cells via the epidermal growth factor receptor. Biochem. J. 2000 (in press).

[46] Mannon PJ, Mervin SJ, Sheriff-Carter KD. Characterization of a Y1-preferring NPY/PYY receptor in HT-29 cells. Am J Physiol 1994;267:G901-G907.

[47] Mannon PJ, Raymond JR. The neuropeptide Y/peptide YY Y1 receptor is coupled to MAP kinase via PKC and Ras in CHO cells. Biochem Biophys Res Commun 1998;246:91-4.

[48] Marais R, Light Y, Mason C, Paterson H, Olson MF, Marshall CJ. Requirement of Ras-GTP-Raf complexes for activation of Raf-1 by protein kinase C. Science 1998;280:109-12.

[49] McCulloch CR, Kuwahara A, Condon CD, Cooke HJ. Neuropeptide modification of chloride secretion in guinea pig distal colon. Regul Peptides 1987;19:35-43.

[50] Modlin IM, Goldenring JR, Ballantyne GH. In the human colon PYY paracrine modulation of ion transport is tetrodotoxin insensitive. Gastroenterology 1991;100:A471.

[51] Perletti GP, Folini M, Lin H.-c, Mischak H, Piccinini F, Tashjian AH. Overexpression of protein kinase $\mathrm{C}$ epsilon is oncogenic in rat colonic epithelial cells. Oncogene 1996;12:847-54.

[52] Playford RJ, Boulton R, Ghatei MA, Bloom SR, Wright NA, Goodlad RA. Comparison of the effects of transforming growth factor a and epidermal growth factor on gastrointestinal proliferation and hormone release. Digestion 1996;57:362-7. 
[53] Playford RJ, Domin J, Beacham J, Parmar KB, Tatemoto K, Bloom SR, Calam J. Preliminary report: role of peptide YY in defence against diarrhoea. Lancet 1990;335:1555-7.

[54] Playford RJ, Marchbank T, Mandir N, Higham A, Meeran K, Ghatei MA, Bloom SR, Goodlad RA. Effects of keratinocyte growth factor on gut growth and repair. J Pathol 1998;184:316-22.

[55] Pouyssegur J, Seuwen K. Transmembrane receptors and intracellular pathways that control cell proliferation. Annu Rev Physiol 1992;54: 195-210.

[56] Prenzel N, Zwick E, Daub H, Leserer M, Abraham R, Wallasch C, Ullrich, A. EGF receptor transactivation by G-protein-coupled receptors requires metalloproteinase cleavage of proHB-EGF. Nature.; 1999;402:884-8.

[57] Rao GN, Delafontaine P, Runge MS. Thrombin stimulates phosphorylation of insulin-like growth factor-1 receptor, insulin receptor substrate-1, and phospholipase $\mathrm{Cg} 1$ in rat aortic smooth muscle cells. J Biol Chem 1995;270:27871-5.

[58] Reddy BS, Maeura Y. Tumor promotion by dietary fat in azoxymethane-induced colon carcinogenesis in female F344 rats; influence of amount and sources of dietary fats. J Natl Cancer Inst 1984;72:74550.

[59] Sandler R. Epidemiology and risk fators for colorectal cancer. Gastroenterol Clinics N Am 1996;25:717-36.

[60] Saria A, Beubler, E. Neuropeptide Y (NPY), and peptide YY (PYY) inhibit prostaglandin $\mathrm{E}_{2}$-induced intestinal fluid, and electrolyte secretion in the rat jejunum in vivo. Eur. J. Pharmacol 1985;119:47-52.

[61] Savage AP, Gornacz GE, Adrian TE, Ghatei MA, Goodlad RA, Wright NA, Bloom SR. Is raised plasma peptide YY after intestinal resection in the rat responsible for the trophic response? Gut 1985; 26:1353-8

[62] Shigeri Y, Fujimoto M. Two different signal transductions of neuropeptide Y1 receptor in SK-N-MC cells. Biochem Biophys Res Comm 1992;187:1565-71.

[63] Soltoff SP. Related adhesion focal tyrosine kinase and the epidermal growth factor receptor mediate the stimulation of mitogen-activated protein kinase by the G-protein-coupled $\mathrm{P}_{2 \mathrm{Y} 2}$ receptor. J Biol Chem 1998;273:23110-7.

[64] Spiller RC, Trotman RF, Adrian TE, Bloom SE, Misiewicz JJ, Silk DB. Further characterization of ileal brake reflex in man-effect of ileal infusion of partial digests of fat, protein, and starch on jejunal motility and release of neurotensin, enteroglucagon, and PYY. Gut 1988;29:1042-51.

[65] Stadler J, Stern HS, Yeung KS, McGuire V, Furrer R, Marcon N, Bruce WR. Effect of high fat consumption on cell proliferation activity of colorectal mucosa and on soluble faecal bile acids. Gut 1988;29:1326-31.

[66] Tsai W, Morielli AD, Peralta EG. The m1 muscarinic acetylcholine receptor transactivates the EGF receptor to modulate ion channel activity. EMBO J 1997;16:4597-605.

[67] Unden A, Bartfai T. Regulation of neuropeptide Y (NPY) binding by guanine nucleotides in the rat cerebral cortex. FEBS Lett 1984;177: 125-8.

[68] van Biesen T, Hawes BE, Raymond JR, Luttrell LM, Koch WJ, Lefkowitz, RJ. $\mathrm{G}_{\mathrm{o}}$-protein a-subunits activate mitogen-activated protein kinase via a novel protein kinase $\mathrm{C}$-dependent mechanism. J Biol Chem 1996;271:1266-9.

[69] van Corven EJ, Groenink A, Jalink K, Eichholtz T, Moolenaar WH. Lysophosphatidate-induced cell proliferation: identification and dissection of signaling pathways mediated by G proteins. Cell 1989;59: 45-54.

[70] Voisin T, Bens M, Cluzeaud F, Vandewalle A, Laburthe, M. Peptide YY receptors in the proximal tubule PKSV-PCT cell line derived from transgenic mice. J Biol Chem 1993;268:20547-20544.

[71] Voisin T, Rouyer-Fessard C, Laburthe M. Distribution of common peptide YY-neuropeptide Y receptor along rat intestinal villus-crypt axis. Am J Physiol 1990;258:G753-G759.

[72] Wharton J, Gordon L, Byrne J, Herzog H, Selbie LA, Moore K, Sullivan MHF, Elder MG, Moscoso G, Taylor KM, Shine J, Polak JM. Expression of the human neuropeptide tyrosine Y1 receptor. Proc Natl Acad Sci USA 1993;90:687-91.

[73] Willett W. The search for the causes of breast and colon cancer. Nature 1989;338:389-94.

[74] Willett WC, Stampfer JM, Colditz GA, Rosner BA, Speizer FE. Relation of meat, fat, and fiber intake to the risk of colon cancer in a prospective study among women. N Engl J Med 1990;323:1664-72.

[75] Zukowska-Grojec Z, Pruszczyk P, Colton C, Yao J, Shen GH, Myers AK, Wahlestedt C. Mitogenic effects of neuropeptide $\mathrm{Y}$ in rat vascular smooth muscle cells. Peptides 1993;14:263-8. 